УДК 551.4:551.435.1:504.064.3(477.83)

\title{
RIVERBED DEFORMATIONS IN THE UPPER DNISTER CATCHMENT UNDER GRAVEL-PITS EXPLOITATION
}

\author{
Andriy Mykhnovych, Olha Pylypovych \\ Ivan Franko National University of Lviv, Ukraine
}

\begin{abstract}
Paper deals with the short analysis of vertical and horizontal river beds deformations which are developed due to intensive gravel mining within the river channels and floodplains of the Upper Dnister catchment. These processes and water regime changes have noticeable impact upon the hydroecological state of the small river systems and ecological problems in their catchments. Regressive river bed erosion is especially dangerous for buildings, economical objects, engineering and transport infrastructure. Based on the main results obtained due to the analysis of the recent monitoring, field, stationary and semi-stationary observations data the scales, main tendencies and intensity of erosion and accumulation processes have been ascertained. Main ecological consequences and optimization measures for the processes regulating and risk mitigation are discussed as well.
\end{abstract}

Key words: River bed deformation, river system, erosion, accumulation.

Introduction. Riverbed deformations are a consequence of erosion accumulation processes complex development in the riverbeds. They cause changes in the river system functioning regime, transformation of the river system structure, destroying of living and economical buildings and infrastructure within the floodplain. Trends, scales and intensity of the riverbed deformations are determined by the complex of nature and manmade factors $[1,5,7,8,9]$, which work differently in the catchments of different areas, ranks, type and level of economic development.

The main aim of the investigation is assessment of the scales, trends, intensity, causes and effects of horizontal and vertical riverbed deformations as well as the risk of engineering constructions destroying in the river basins.

Research of riverbed and floodplain complexes in the Ukrainian Carpathians were started in 1960-s and were based on the results of the previous large geomorphologic and hydrographical investigations [3,9]. For instance in 1950-s the large and complex river investigations were carried out with the aim of hydro-energetic potential evaluation and hydropower constructing planning for the upper mountain Dnister River tributaries. Such investigations were continued for the river channel and riverbed processes regulating in 1960-s - 1980-s. The horizontal deformations of the Opir riverbed have been analyzed also in 2000. Some research concerning oil pipeline "Druzhba" reconstruction and for the aim of river banks protection on the Carpathian tributaries of the Dnister River were carried out in 2005. Much attention to the riverbed processes research were paid also by the scientists of the Ivan Franko National University of Lviv, National universities of Chernivtsi and Kyiv, Ukrainian Hydrometeorological Research Institute, Ukrainian Research Institute of Hydrotechnics and Melioration and others [3, 4, 5, 8, 9].

(C) Mykhnovych A., Pylypovych O., 2017 
Our research of the riverbed deformations mostly refer to the representative model rivers in the upper Dnister basin. The main objectives of the research are distribution, scale, tendencies and intensity of the riverbed deformations development, activization causes and risk assessment within the river basin.

Materials and methods. Research was based on data of stationary and semistationary observations, field investigations, remote sensing materials, statistical, cartographical, cartometrical, historic-geographical and GIS analyses, $Q=f(H)$ curves and long-term suspended loads graphs comparison and analysis. Scales, trends and intensity of riverbed vertical deformations analysis was based on comparing series of cross-sections and longitudinal profiles of different time and $Q=f(H)$ curves built on the base of data of the State Committee on Hydrometeorology published in the special bulletins.

For the studied cross-sections the overall trends and character of deformation were ascertained (erosion or accumulation), their quantitative assessment for the observation period (from 10 to 32 years), average intensity have been calculated ( $\mathrm{mm}$ per year). With the aim of spatial analysis of the deformations the parameters were calculated for same periods to obtain comparable results. Calculation results were visualized by GISmaps.

Main results and discussion. Results of the analysis testify that riverbeds of the Precarpathian part of the Dnister basin are very unstable and characterized by intensive bank and bottom erosion. Average tempo of bottom erosion varies from 1 to 60 $\mathrm{mm} /$ year during last $20-30$ years. Bank erosion amounts from centimeters to $1,5-3,7$ meters per year. Concerning the changes which have been ascertained by the longitudinal profiles analysis, they are caused by several factors impact: a) manmade activity (gravel-pits exploitation on the floodplains and in the riverbeds as well, river channel straightening, runoff regulating etc.); b) natural or natural-manmade factors (climate change, water runoff, forestry and land use changes etc.) Riverbed changes scales testify about cutting down trends (from mm per year to $2-3$ meters for last $20-$ 25 years). At the same time in the Precarpathian parts of the rivers alluvium accumulation processes are observed. But erosion processes are predominant in the river basins.

Maximal intensity of erosion is observed in the following rivers: Stryvihor (near Luky; 65,5 mm/year), Ruzhanka (near Ruzhanka; $45 \mathrm{~mm} /$ year), Slavs'ka (near Slavs'ke; $35 \mathrm{~mm} /$ year) and Stryi (Verkhnie Syniovydne; 31,25 $\mathrm{mm} /$ year). Accumulation is representative for the rivers Dnister near Sambir (20 mm/year), Tys'menytsia near Drohobych (20 mm/year), Shchyrka near Shchyrets' (7,81 $\mathrm{mm} /$ year) and Bystrytsia near Ozymyna $(6,25 \mathrm{~mm} / \mathrm{year})$. Relatively stable riverbeds (deformation is not more than $3 \mathrm{~mm} /$ year) are representative for the rivers Dnister near Rozdil, Stryvihor near Khyriv.

To evaluate applicability of the used methods the obtained results have been compared with the results and information from other sources. Intensive erosion of the Dnister riverbed near Strilky is confirmed by the results of a few measurements implemented by the Research Institute "Lvivdiprovodhosp". It was ascertained clear trend to cutting down of the riverbed caused by gravel mining within the open pit near Torchynovychi village. Intensive cutting down of the Stryi River due to regressive erosion is confirmed by the results of the field investigations carried out in 1997 - 
2010. The field investigations in 2010-2015 have confirmed intensive erosion and riverbed cutting in the river systems of Yablun'ka, Oriava and Opir as well.

The main causes of the erosion processes activization in the Dnister headwaters (upstream Sambir), the Stryi River and its tributaries are gravel intake in the channel open pits near Stryi city, Torchynovychi and water runoff increase. Effects of the open pits exploitation are reflected on the longitudinal profiles of the analyzed rivers. Upstream the gravel-pits the Dnister does not overflow the river banks even during floods of $1 \%$ probability. This conclusion is confirmed also by the character of vertical deformations distribution and development in other river systems of the Ukrainian Carpathians $[3,5,9]$.

Regressive erosion in the Opir catchment is faster than in the Stryi River basin because specific geomorphologic conditions and hypsometrical and morphometric differences which are overlapped upon man-made factors. Opir riverbed is located mostly in the transverse segments of the valley and is characterized by higher inclination. Thereto the eastern part of the Skole Beskyds where the Opir watershed is located is characterized by higher altitudes and slope inclination comparing to the Stryi basin where the riverbed is situated generally within the longitudinal valleys.

Activization of the Stryvihor riverbed cutting down is caused by hydrotechnical measures (like the Stryvihor and Dnister riverbeds straightening and dikes building) which have been implemented within the Upper-Dnister Lowland with the aim of flood protection. These factors caused increasing riverbed cutting down during the flood events.

Another important factor of this process (like in the Yablun'ka catchment for instance) is gravel withdrawal overlapped on the river channels straightening in the Dnister river basin. Gravel-pebble material withdrawal and the riverbeds straightening are typical almost for all river systems in the upper part of the Dnister basin. Works and material withdrawal volumes with the aim of riverbeds regulating and clearing are presented in Table 1.

The most important consequence of the riverbed erosion in the Upper Dnister river basin is dangerous geomorphologic and hydrological processes activization like bank erosion, landslide processes lengthwise the river (especially in lower parts of the valleys), landslides and mudflows on the steep slopes (characteristically for the riverbed segments with regressive erosion in the middle and upper parts of the river systems). For example in Novyi Kropyvnyk village (within the Stryi river valley) we have a high risk of the old wooden church (architectural monument) destroying due to the intensive vertical riverbed deformations. In Pidbuzh village (Bystrytsia River) the private houses are threatened. In Velyka Sushytsia (Sushytsia River is a tributary of the Stryvihor River) - the cemetery is undermined, and in Turye village (Topilnytsia River - the right mountain tributary of the Dnister headwaters) there is a threat of the bridge destroying and so on (Table 2).

In the studied region these geomorphologic effects are specially intensified in the conditions of uncontrolled deforestation and building. Due to high probability of the regressive erosion upstream advancement to the upper parts of the Stryi river basin with less forestry we should expect the landslides and mudflows activization risk increasing during the extreme precipitations and intensive snow melting. Intensified drainage and groundwater runoff increasing during low water periods is one more effect of the intensive riverbed cutting down in the studied area. 
Table 1. The river basins where works on channel regulating and sand-gravelpebble sediment material withdrawal are planed in the year 2016 (according to the Lviv Regional Water Resources Department)

\begin{tabular}{|c|c|c|c|}
\hline $\begin{array}{l}\text { River } \\
\text { basin }\end{array}$ & Settlement & $\begin{array}{c}\text { Length } \\
\text { of the } \\
\text { regulated } \\
\text { or cleared } \\
\text { riverbeds }\end{array}$ & $\begin{array}{l}\text { Average } \\
\text { withdrawal } \\
\text { volume, } \\
\mathbf{m}^{3} / \mathrm{km}^{2}\end{array}$ \\
\hline Stryvihor & $\begin{array}{l}\text { Babyno, Pyniany, Biskovychi, Chernykhiv, Chapli, } \\
\text { Murovane }\end{array}$ & 1,6 & 20,44 \\
\hline Bystrytsia & $\begin{array}{l}\text { Stupnytsia, Mokriany, Vynnyky, Urizh, } \\
\text { Pidmonastyrok, Zvir, Monastyrets', Cherkhava }\end{array}$ & 5,04 & 102,30 \\
\hline Stryi & $\begin{array}{l}\text { Dovhe, Hirske, Novyi Kropyvnyk, Maidan, Volia } \\
\text { Hnizdychivska, Ivanivtsi, Zarichchia, Zhydachiv, } \\
\text { Zalisky, Verkhnie Syniovydne, Sopit, Luhy, } \\
\text { Hodovychi, Stryhantsi, Verchany, Dobriany, } \\
\text { Liubyntsi, Turka, Verkhnie Vysots'ke, Nyzhnie } \\
\text { Vysots'ke, Ilnyk, Losynets', Zavadivka, Yavora, } \\
\text { Isayi, Komarnyky }\end{array}$ & 8,65 & 80,42 \\
\hline Svicha & $\begin{array}{l}\text { Melnychi, Zhuravno, Dubravka, Zarichne, Mali } \\
\text { Didushychi }\end{array}$ & 1,37 & 25,78 \\
\hline Sukil & Volia & 0,1 & 3,62 \\
\hline Dnister & $\begin{array}{l}\text { Busovysko, Tershiv, Spas, Verkhniy Luzhok, } \\
\text { Strilky, Sushytsia, Torchynovychi, Strashevychi, } \\
\text { Zavadka, Sozan', Koblo, Zalisky, Borodchytsi, } \\
\text { Bukavyna, Naditychi, Pidhirtsi, Tuzhanivtsi }\end{array}$ & 21,55 & 5,41 \\
\hline
\end{tabular}

Matching of the discharge curves for different time in combination with riverbed cross-sections analyses have been allowed to determine different types of the riverbed vertical deformations. As a criteria of determination the ratio between the deformation in the central and banks parts of the riverbed was used. First type of negative deformations is characterized by the even cutting down with keeping of the form of riverbed cross-section. This type is observed in the condition of high intensity of cutting down and relatively low water runoff increasing. This type is characteristic for the Dnister river channel (upstream Strilky), most of its left tributaries and the Opir river system.

The second type of deformations is characterized by the excess of the cutting rate in the central part of the riverbed with progressive deepening. This type develops in the conditions of sudden intensifying riverbed erosion processes which often occurred due to neotectonic raise of the territory, sudden erosion basis lowering and noticeable water runoff increasing. For the third type of deformations riverbed cutting in the bank parts exceeds the riverbed cutting in the water-way part. By this type some adjustment of the riverbed cross-section is observed. Usually this type is developed due to periodic migration of the flow stream from one river bank to another combined with water runoff increase.

The Yablun'ka River is characterized by intensive riverbed deformations during last decades. The river system structure has been strongly changed in the period $1940-$ 2000, especially the streams of 1-st and 2-nd orders (according to Strahler-Filosofov 
Table 2. The areas where dangerous geomorphologic processes threaten to engineering constructions or buildings due to gravel-pebble material withdrawal in the open pits

\begin{tabular}{|c|c|c|c|}
\hline Settlement & River & Threatened object & Dangerous process \\
\hline Lastivka & Stryi & & $\begin{array}{c}\text { Intensive horizontal } \\
\text { deformations; Gravel-pebble } \\
\text { withdrawal in the riverbed }\end{array}$ \\
\hline N. Kropyvnyk & Stryi & $\begin{array}{l}\text { Wooden church of } \\
\text { XVIII century, the } \\
\text { road and private } \\
\text { economies }\end{array}$ & Bank erosion \\
\hline Smilna & Bystrytsia & $\begin{array}{l}\text { Village road and } \\
\text { private economies, } \\
\text { the cemetery and } \\
\text { wooden church of } \\
1905\end{array}$ & $\begin{array}{l}\text { Vertical and horizontal } \\
\text { deformations }\end{array}$ \\
\hline $\begin{array}{l}\text { Velyka } \\
\text { Sushytsia }\end{array}$ & $\begin{array}{l}\text { Stryvihor right } \\
\text { tributary }\end{array}$ & The cemetery & $\begin{array}{c}\text { Vertical deformations, bank } \\
\text { erosion }\end{array}$ \\
\hline Pidbuzh & Bystrytsia & $\begin{array}{l}\text { Village road and } \\
\text { private economies }\end{array}$ & $\begin{array}{c}\text { Intensive horizontal } \\
\text { deformations }\end{array}$ \\
\hline Dobromyl & $\begin{array}{c}\text { Vihor } \\
\text { (Sian basin) }\end{array}$ & Road & $\begin{array}{c}\text { Intensive horizontal } \\
\text { deformations }\end{array}$ \\
\hline Turye & Topilnytsia & The bridge & Riverbed erosion \\
\hline Lopushnytsia & $\begin{array}{c}\text { Stryvihor left } \\
\text { tributary }\end{array}$ & Road & Vertical deformations, landslide \\
\hline Strilky & $\begin{array}{c}\text { Dnister, } \\
\text { Yasenytsia }\end{array}$ & $\begin{array}{c}\text { Bridge, road, private } \\
\text { economies }\end{array}$ & $\begin{array}{c}\text { Intensive horizontal and vertical } \\
\text { deformations (Figure 1) }\end{array}$ \\
\hline Staryi Sambir & Dnister & Railway & Bank erosion \\
\hline Slavs'ke & Slavs'ka & Road, bridge & $\begin{array}{c}\text { Intensive horizontal } \\
\text { deformations }\end{array}$ \\
\hline $\begin{array}{l}\text { Voloshynove, } \\
\text { Staryi Sambir }\end{array}$ & Yablun'ka & $\begin{array}{l}\text { Village road, private } \\
\text { economies }\end{array}$ & $\begin{array}{c}\text { Gravel-pebble withdrawal } \\
\text { Vertical and horizontal } \\
\text { deformations }\end{array}$ \\
\hline Korostiv & Oriava, Butyvlia & & $\begin{array}{l}\text { Intensive Vertical and } \\
\text { horizontal deformations (Figure } \\
\text { 2) }\end{array}$ \\
\hline Krushelnytsia & Stryi & Private economies & $\begin{array}{l}\text { Riverbed bifurcation, bank } \\
\text { erosion }\end{array}$ \\
\hline $\begin{array}{l}\text { Verkhnie } \\
\text { Syniovydne }\end{array}$ & Opir & The bridge & $\begin{array}{c}\text { Intensive gravel-pebble material } \\
\text { withdrawal in the riverbed } \\
\text { under the bridge }\end{array}$ \\
\hline
\end{tabular}

classification scheme). The main cause of river system structure transformation and intensive riverbed deformations is settlement, agricultural, hydro-technical impacts upon the catchment and intensive gravel mining activity within the river channel and floodplains. Example of external influence on the Yablun'ka river system is gravel quarry exploitation in the Dnister river valley (near Torchynovychi and Strashevychi villages) downstream Yablun'ka junction. Erosion basis lowering near Staryi Sambir causes intensifying of vertical deformations of the Yablun'ka and its tributaries riverbeds. High speeds of water flow (up to $3,5 \mathrm{~m} / \mathrm{s}$ ) advantage the bank side erosion. 


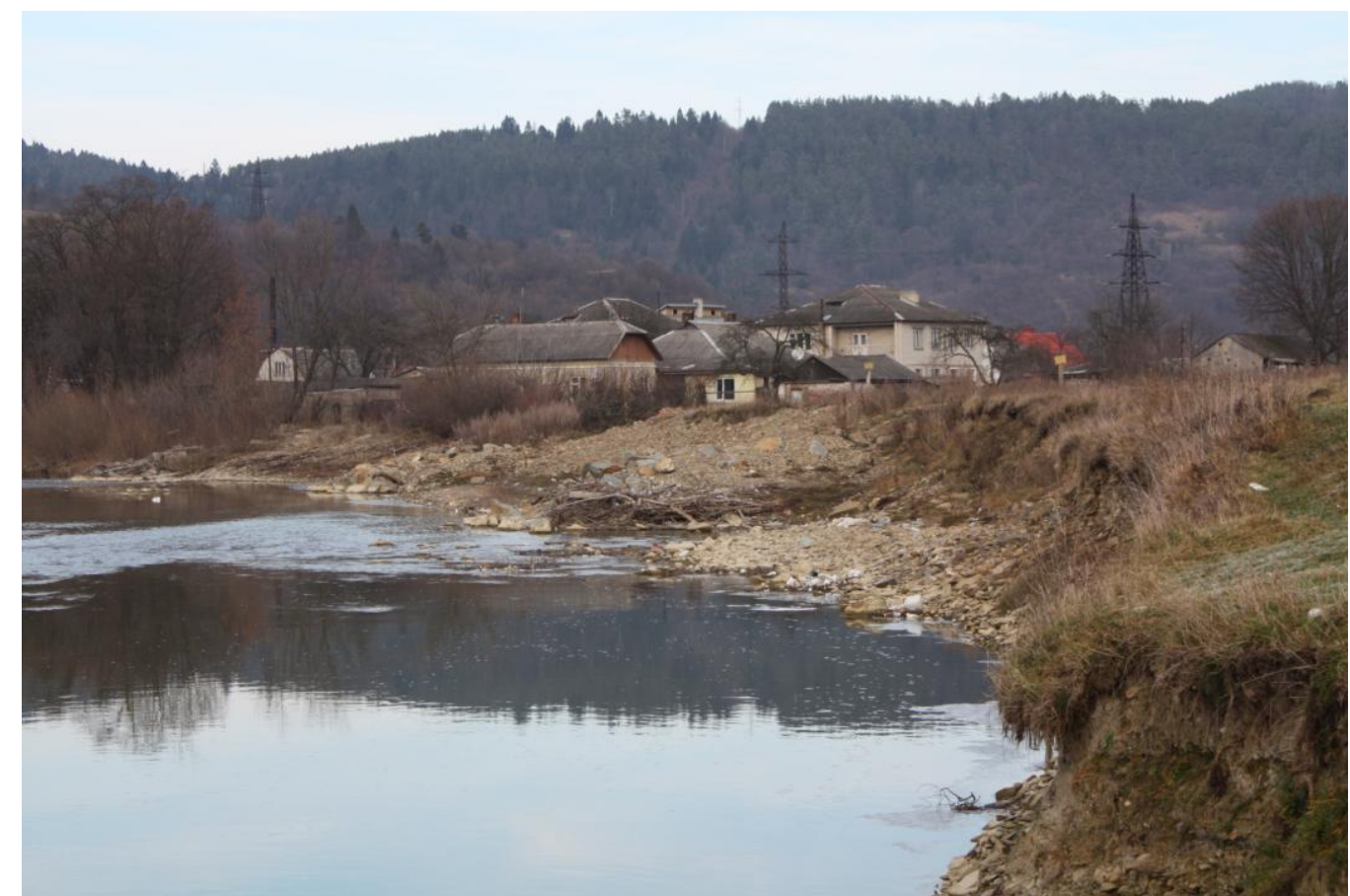

Figure 1. Horizontal riverbed deformations on the Dnister River due to the gravelpebble withdrawal downstream of the river

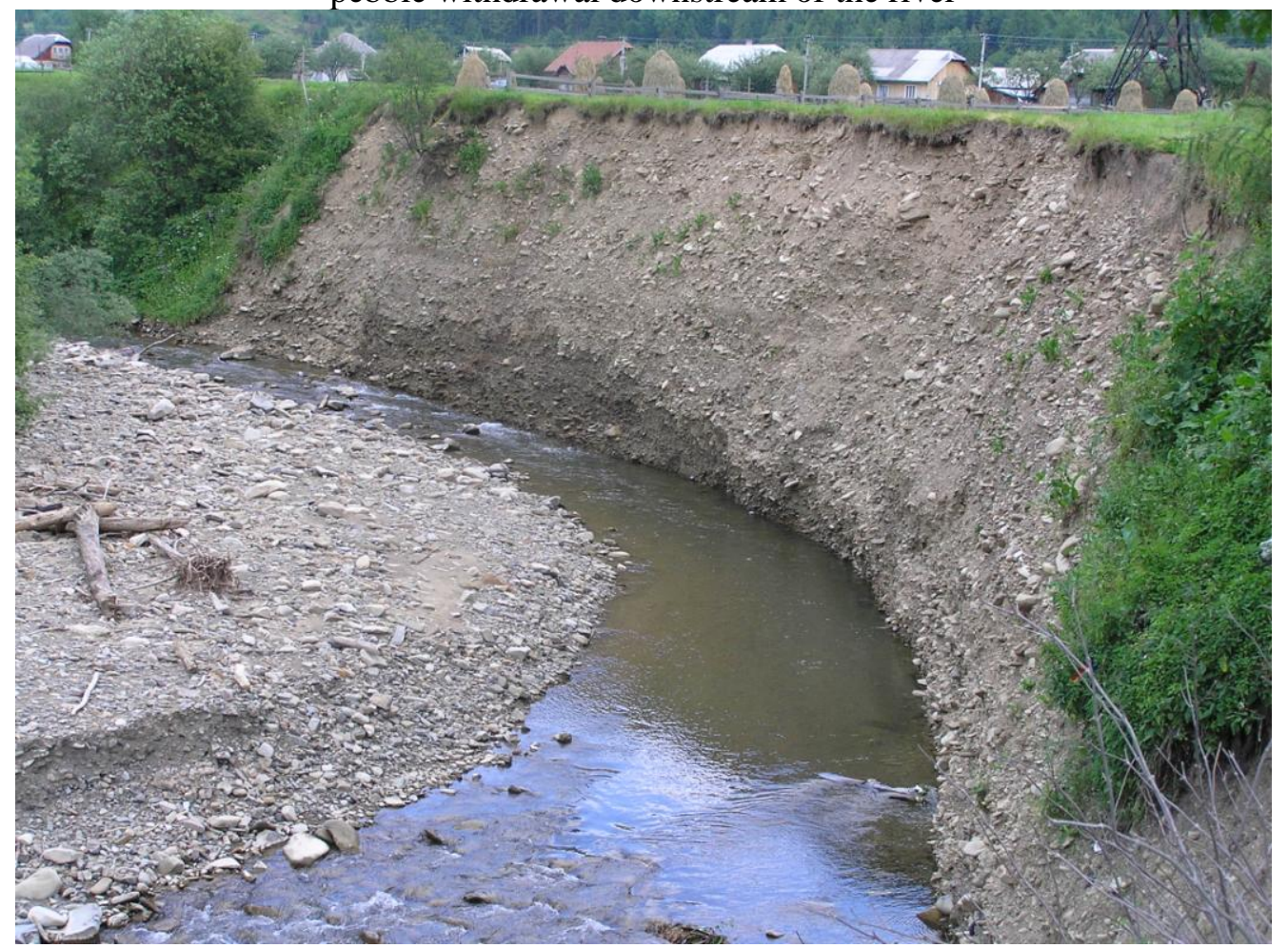

Figure 2. Intensive vertical deformations in the Butyvlia riverbed as a result of gravel-pebble withdrawal downstream in the Oriava River 
The river valley shape varies from V-typed in the upper part to U-typed in the lower one. Geologically the river valley is composed (up to $5 \mathrm{~m}$ depth) by the recent alluvium represented by gravel-pebble sediments filled with sand and boulders inclusion up to $10 \%$.

The monitoring data do not reflect enough the climatic conditions of the different studied catchments due to noticeable discreteness of the meteorological parameters. Meanwhile the analysis of long-term observation data set from Sambir station (more than 100 years) testifies that there were not huge changes in meteorological parameters which could be able to cause intensive changes in river systems structure and riverbed processes.

The first documents concerning the settlements on the study area refer to XV century. All settlements here have the valley type of settling along the rivers. This is the factor of rising risk of morphodynamical processes riverside due to intensifying economical activities (building, agriculture, water use, gravel mining etc). Beside that these activities form additional geoecological tension in the river basins due to waste waters and garbage dumping, exceeding fertilizer input riverside, drainage works and so on. In average $50-80 \%$ of the river bank belt is affected by the human activity. The gravel-pebble fields with mining in the riverbed open pits for building and commerce are especial dangerous. Slopes of the river basin also are affected by the intensive agricultural influence.

In XVIII century arable lands occupied about $32 \%$ of the Yablun'ka catchment area. By the middle of XX century the arable areas were increased two times (Strilbychi, Voloshynove). Somewhere (Bilych, Stara Sil) the share of arable lands was decreased due to increasing pasture and hay fields.

There are no essential changes in the structure of forested areas using. The analysis of the different time topographical maps of the scale 1:100 000 has shown increasing forestation from $31,2 \mathrm{~km}^{2}$ in $1940\left(36,8 \%\right.$ of the catchment area) to $36,5 \mathrm{~km}^{2}$ in 2000 $(43,0 \%$ of the basin area).

Gravel mining in the riverbed open pits downstream has very strong impact upon the riverbed deformations upstream in the Upper Dnister basin. Erosion basis lowering near Torchynovychi and Strashevychi causes regressive erosion, channel cutting down and vertical deformations in the river systems upstream. According observations results [6] the Dnister river bottom near Yablun'ka junction has been cut up to 4,5 meters since 1969. As the result the inclination of Yablun'ka has increased from 0,006 to $0,012 \%$ and channel erosion has been intensified. Figure 3 shows the dynamics of the Yablun'ka riverbed cross-sections between 1987 and 1997. Average erosion intensity in this period was $8-10 \mathrm{~cm}$ per year.

By the gravel-pits mining within the riverbeds and floodplains the deep declines up to a few kilometers width are formed. For example the large open pit located between Torhanovychi and Strashevychi has width of $1,2 \mathrm{~km}$. Its width significantly exceeds the Dnister riverbed width. This open pit changes the riverbed morphometric and the flow characteristics significantly and causes the deficit of suspended loads downstream in the channel and the intensive erosion upstream. These processes cause rapid increase of the riverbed stability index. Self regulation processes take parts within the riverbed and in the whole catchment. 
The riverbed stability index is the parameter which characterizes the self regulation processes velocity in river channel. Concerning the Yablun'ka River this index has been calculated at the first time by the method proposed by M. Velikanov: $\mathrm{y}=$ $d^{*}(h * I)-1$, where y - riverbed stability index, $d$-average diameter of the sediments, $h$ - river flow depth, $I$ - riverbed inclination. According to the calculations the index changed between 0,65 in 1987 to 2,2 in 1997. 3,8 times increasing testifies about rapid activization of the riverbed processes. For example the investigations of $\mathrm{K}$. Berkovich and L. Zlotina have shown the same riverbed stability index for the Dnister River between Bendery and Dubosary towns. Due to the alluvium withdrawal which exceeds the riverbed-forming suspended load runoff the stability index has increased 5 times for three years $[1,2]$. The stable riverbed is characterized by the stability index $y=15$. In 2005 in the Yablun'ka riverbed on the distance $1 \mathrm{~km}$ from the mouth 7 gabions have been constructed against intensive vertical deformations.

a)

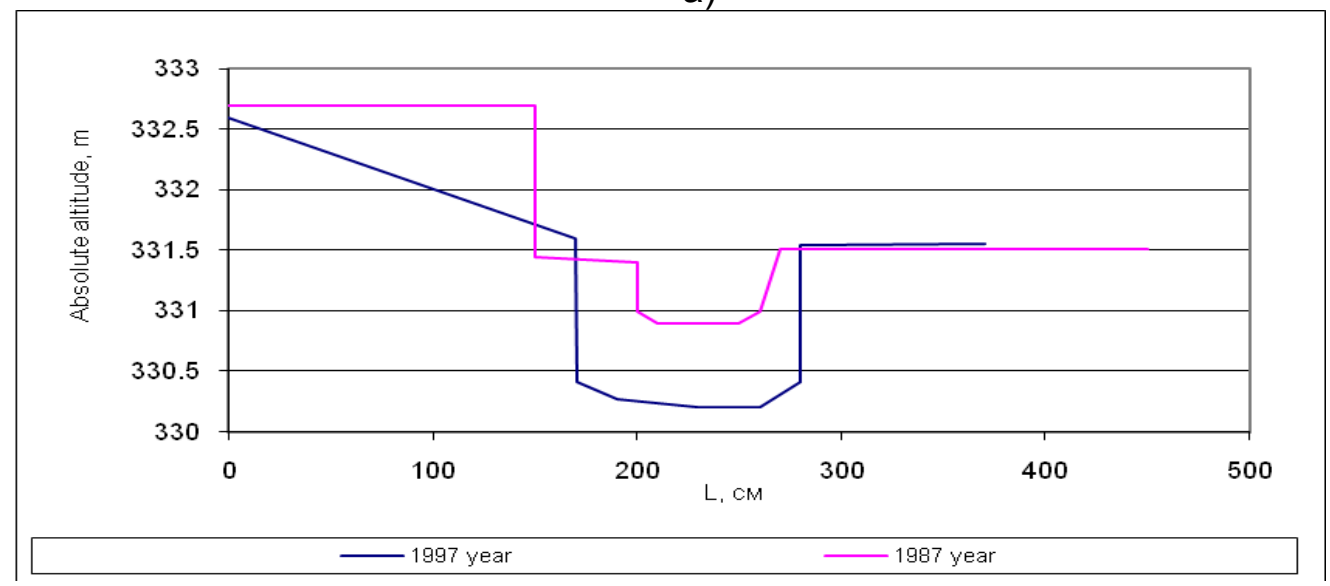

b)

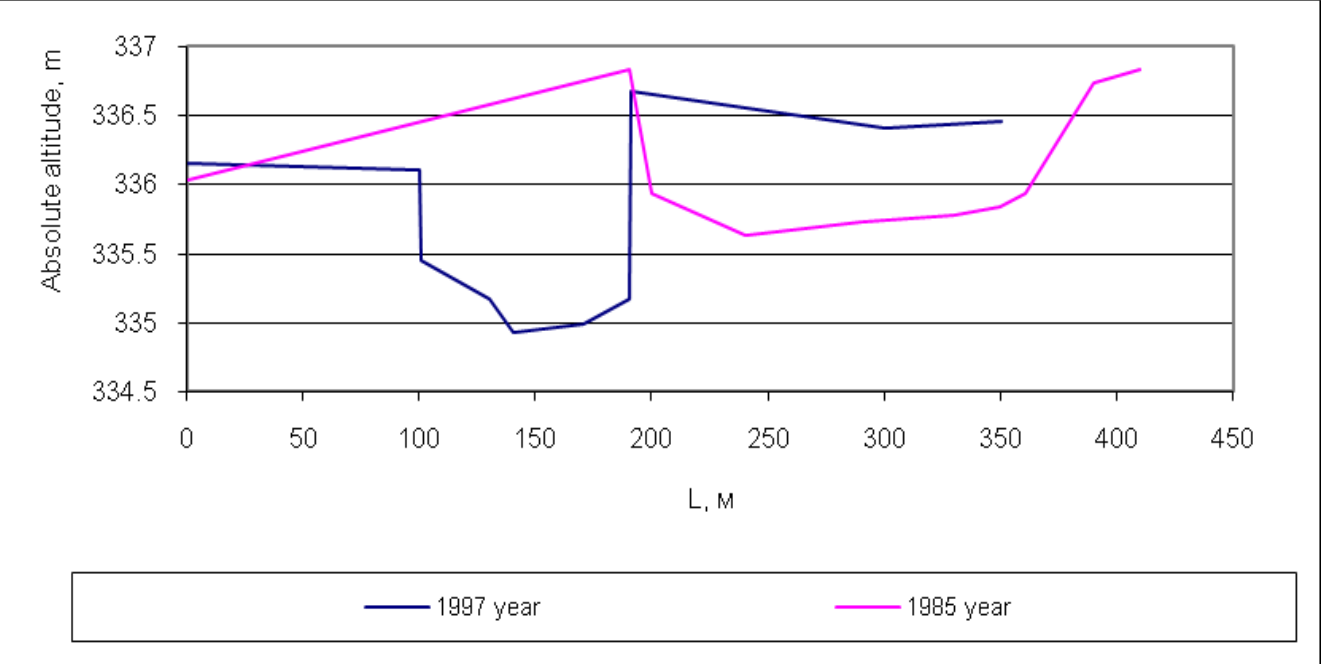

Figure 3. Changes of the cross-sections of the Yablun'ka riverbed for the period 1985 - 1997 at a distance of a) $21 \mathrm{~m}$ from the mouth; b) $420 \mathrm{~m}$ from the mouth 
According to our observations such measures solved the problem partly and temporary only. All gabions have been destroyed by the stream flow and vertical deformations are very intensive again. This conclusion is confirmed by the field investigations in March 2016 (Figure 4).

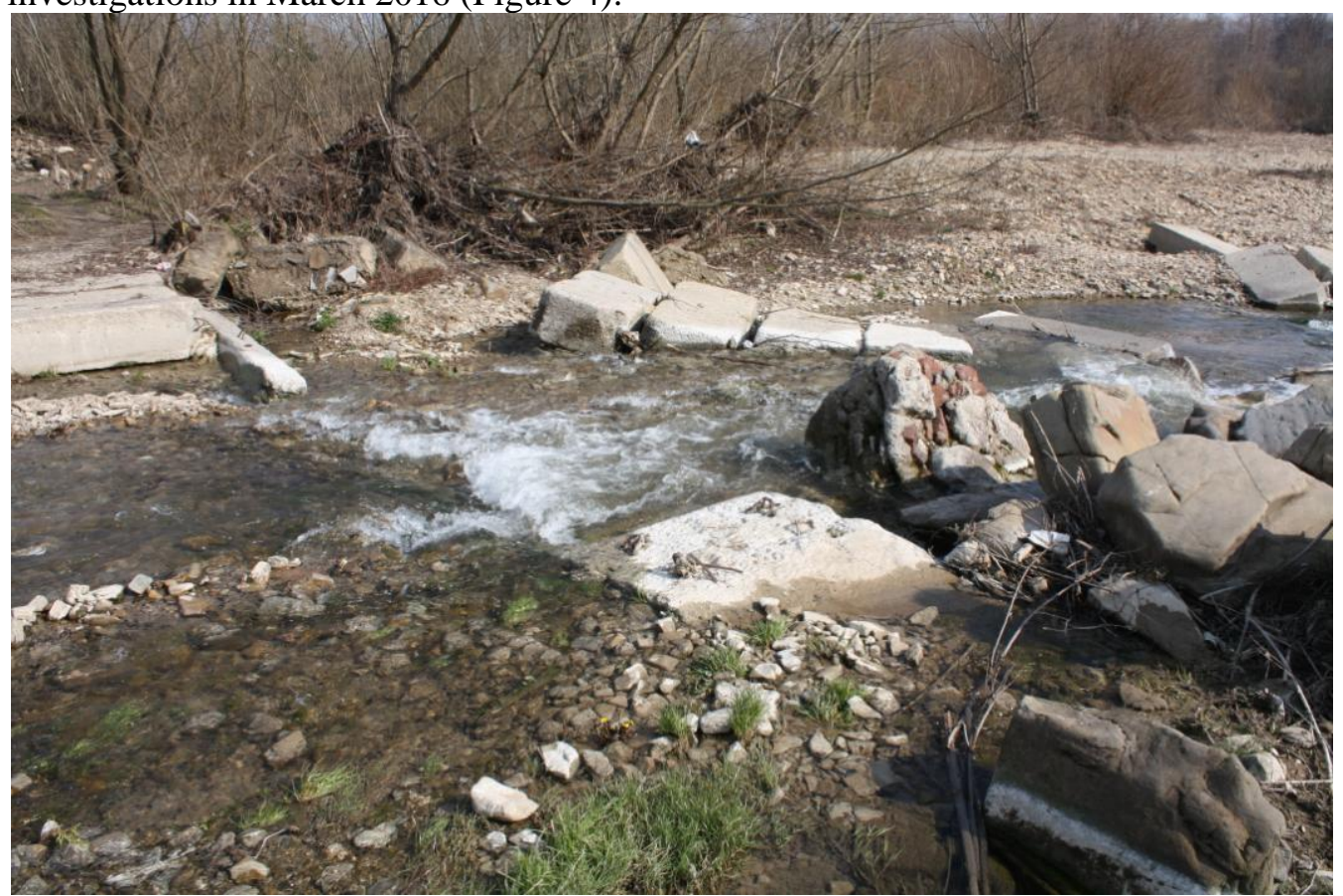

Figure 4. Destroyed gabions because of intensive vertical deformation of the riverbed

(March 2016)

Conclusions. The scales and intensity of the riverbed deformations development are determined by: the relative high amplitudes of altitude (from 50-200 to $250-550$ $\left.\mathrm{m} / \mathrm{km}^{2}\right)$; the significant depth of erosion cutting of the rivers $(260-400 \mathrm{~m}$ and more); high water flow speed (from $1,0-1,5 \mathrm{~m} / \mathrm{s}$ to $3,0-5,0 \mathrm{~m} / \mathrm{s}$ during the floods); significant slope inclination; weak resistance of the Carpathian flysch to denudation; climatic characteristics, especially large amount and high intensity of precipitation (50 $-150 \mathrm{~mm}$ per day and more).

Total deforestation of the slopes and gravel-pebble withdrawal from the open pits in the riverbeds and floodplains are main kind of economic activity which influences upon riverbed deformations development and river system transformations.

The ascertained parameters of riverbed deformations scales and intensity are used for recommendations and substantiation concerning dangerous processes prevention. Particularly, it is necessary to repair the gabions and other anti-erosion constructions in the riverbeds of mountain and premountain areas (Dnister River near Strilky, Verkhniy Luzhok, Busovysko, Tershiv, Strilkovychi, Khatky, Ralivka, Susoliv, Rozvadiv, Tys'menytsia and Bar rivers near Mykhailevychi, Bystrytsia River near Dorozhiv, Mokriany, Olenka River near Strilky, Stryvihor River near Murovane, Zarichne, Yaziv, Monastyrets', Stryi River near Nyzhnie Vysots'ke, Il'nyk, Losynets', Nyzhnia Stynava, Kuty, Slavs'ka River near Slavs'ke and Yablun'ka River (lower part and river mouth). 
The Yablun'ka River by the morphometric characteristics belongs to the small rivers with low resistance to external influences. The main kinds of economic activity are agriculture, farming, gravel-pebble mining, and forestry. Since the share of arable lands was not changed significantly, the dominant man-made factor of misbalance of the river system is gravel-pits exploitation.

The river systems reaction is the following: river system structure transformation (decreasing of 1-st and 2-nd order rivers amount); intensive riverbed erosion (the river bottom became deeper more than 4,5 $\mathrm{m}$ since 1969); steep longitudinal profile forming; fast change of the riverbed stability index (from 0,65 to 2,2), change of the river bank height, hydrological regime changes etc.

\title{
REFERENCES
}

1. Беркович К. М. Русловые процессы и русловые карьеры. - Москва, 2005. $109 \mathrm{c}$.

2. Беркович К.М., Злотина Л.З. Расчет стабильности русел в условиях антропогенной нагрузки // География и природные ресурсы, 2003, — № 3.

3. Голояд Б., Сливка Р., Паневник В. Ерозійно-денудаційні процеси в Українських Карпатах. - Івано-Франківськ, 1995. - 114 с.

4. Кравчук Я.С. Геоморфологія Скибових Карпат. Львів: Видавничий центр ЛНУ імені Івана Франка, 2005. - 232 с.

5. Ободовський О. Гідролого-екологічна оцінка руслових процесів (на прикладі річок України). — Київ: Ніка-Центр, 2001. — 274 с.

6. Робочий проект // Берегоукріплення ріки Яблуньки і відновлення вулиці Садової в м. Старий Самбір Львівської області. Ч.1 водогосподарське будівництво. Книга 1 Пояснювальна записка, Львів: 1997. — 29 с.

7. Чалов P. С. Общее и географическое русловедение: Учебное пособие. Москва: Изд-во Московского университета, 1997. - 112 с.

8. Ющенко Ю. Руслознавчі дослідження у Чернівецькому університеті / Українська історична географія та історія географії в Україні. — Чернівці, 2009. - C. $36-37$.

9. Ivan Kovalchuk, Andriy Mykhnovych, Olha Pylypovych and Georgiy Rud'ko. Extreme Exogenous Processes in Ukrainian Carpathians. Book chapter in: Geomorphological impact of extreme weather: Case studies from central and eastern Europe. Loczy Denes. Series: Springer Geography, 2013, Part 1, Pages 53 -67 .

\section{РУСЛОВІ ДЕФОРМАЦЇ̈ У ВЕРХНІЙ ЧАСТИНІ БАСЕЙНУ ДНІСТРА ПІД ВПЛИВОМ ЕКСПЛУАТАЦІї ГРАВІЙНИХ КАР'ЄРІВ}

\author{
Андрій Михнович, Ольга Пилипович \\ Львівський начіональний університет імені Івана Франка
}

У статті представлені короткі результати аналізу руслових деформацій річкових систем верхньої частини басейну Дністра в межах Львівської області. Руслові деформації розвиваються завдяки інтенсивному забору гравію з руслових і заплавних кар'єрів. Спричинені експлуатацією руслових гравійних кар'єрів руслові деформації разом 3 
багаторічними змінами режиму стоку води визначально вливають на гідроекологічний стан річок і розвиток екологічних проблем у їхніх басейнах. Регресивна руслова ерозія становить особливу небезпеку для поселень, господарських об'єктів, інженерних споруд, транспортної інфраструктури та комунікацій. На основі здійснених досліджень, моніторингових даних, результатів польових, стаціонарних i напівстаціонарних досліджень виявлені тенденції і встановлена інтенсивність ерозійно-акумулятивних процесів, масштаби і поширення руслових деформацій і небезпеки руйнувань житлових, господарських, культових об'єктів.

Ключові слова: руслові деформації, річкова система, ерозія, акумуляція. 